
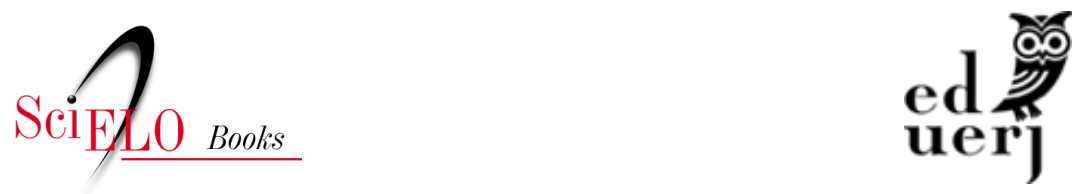

\title{
11. Epílogo
}

Vanessa Massoni da Rocha

\section{SciELO Books / SciELO Livros / SciELO Libros}

ROCHA, V. M. Epílogo. In: Tradução em (ent)revista: Simone Schwarz-Bart e as tradutoras brasileiras [online]. Rio de Janeiro: EDUERJ, 2021, pp. 103-105. Letras UERJ collection. ISBN: 978-65-991111-5-0. https://doi.org/10.7476/9786599111150.0011.

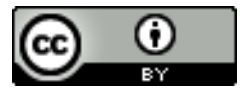

All the contents of this work, except where otherwise noted, is licensed under a Creative Commons Attribution 4.0 International license.

Todo o conteúdo deste trabalho, exceto quando houver ressalva, é publicado sob a licença Creative Commons Atribição 4.0.

Todo el contenido de esta obra, excepto donde se indique lo contrario, está bajo licencia de la licencia Creative Commons Reconocimento 4.0. 


\section{1.}

\section{Epílogo}

Tradução em (ent)revista: Simone Schwarz-Bart e as tradutoras brasileiras se inscreve sob o prisma dos encontros e da alteridade que caracterizam o continente americano e, mais particularmente, a realidade crioula nas Antilhas francesas. Nesse sentido, podemos observar um palimpsesto de diálogos nas tramas da escrita literária e do processo de tradução.

De início, podemos mencionar o fato de as traduções brasileiras de Simone Schwarz-Bart promoverem o encontro de um público leitor não francófono com obras relevantes de expressão francesa. A tradução, como processo de mediação e transporte, tornou acessível ao público brasileiro obras que refletem as artes de fazer e de dizer dos povos que vivenciaram experiências coloniais e pós-coloniais, aproximando de maneira sensível as realidades caribenhas e brasileiras no âmbito romanesco.

No que tange ao encontro dos tradutores com as obras traduzidas, ressaltamos a tradução como descoberta da produção literária antilhana para Estela dos Santos Abreu por intermédio de Schwarz-Bart. Estela traduziu três obras (uma antes e duas após Pluie et vent sur 
Télumée Miracle) do escritor haitiano René Depestre, transformando-se em uma leitora atenta à trajetória editorial desses escritores. No caso de Eurídice Figueiredo, o projeto de tradução foi uma oportunidade singular de aproximar a pesquisa acadêmica centrada em obras antilhanas às descobertas da arte da tradução. Uma década após a publicação de Joãozinho no Além, a pesquisadora divulga a obra Construções de identidades pós-coloniais na literatura antilhana, publicada pela EdUFF, em 1998, em que privilegia, entre outros autores, Simone Schwarz-Bart e analisa brevemente o romance que traduziu.

As entrevistas proporcionaram, igualmente, o encontro das tradutoras com as obras traduzidas há mais de trinta anos. Durante a conversa, tive a oportunidade ímpar de estar ao lado das tradutoras quando reabriram seus exemplares originais e se reencontraram com marcas gráficas (sublinhados, flechas, asteriscos, palavras circuladas, pontos de interrogação e comentários diversos) que configuram uma memória visual e afetiva dos meses em que se debruçaram no processo de tradução. Fui cúmplice de um voltar atrás no tempo, da abertura de livros encerrados há décadas em prateleiras da biblioteca de cada tradutora. E, da obra original, caminharam naturalmente para as traduções empreendidas. Colocaram um livro ao lado do outro, antes de folheá-los com o olhar das lembranças, com as interjeições do reencontro e com as confissões de percalços e alegrias que as acompanharam em suas jornadas.

Estela confessou ter retomado a leitura da tradução após a entrevista, ludibriando o tempo e apreciando, com a experiência da maturidade e dos anos de profissão, sua tradução. Brinca ao reconhecer que proporia, nos dias de hoje, poucas mudanças ao trabalho original. Acaba, assim, por validar a atividade de mais de trinta anos atrás com um orgulho tímido e a alegria de quem fez a escolha afetiva de se dedicar aos meandros da tradução.

Em seguida, podemos aludir a outros reencontros: o que ocorreu entre as duas tradutoras durante o período das entrevistas, entre a 
antiga aluna do Programa de Pós-graduação em Estudos de Literatura da UFF Vanessa Massoni da Rocha e sua professora Eurídice Figueiredo, com quem fez dois cursos de mestrado, e entre Vanessa e Simone Schwarz-Bart - encontro que incluiu Bernard Szwarcbart e Élie Duprey, respectivamente, filho e assistente da autora guadalupense.

Por fim, busca-se que esta obra siga promovendo encontros, valorizando os atores da arte de traduzir e passando em revista experiências de leitura e de tradução. Deseja-se que ela encoraje novas entrevistas e novos diálogos entre produções literárias distintas que possuem muitas interseções entre si. 